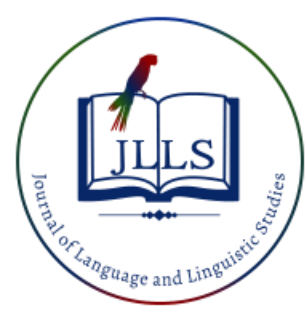

Available online at www.jlls.org

JOURNAL OF LANGUAGE

AND LINGUISTIC STUDIES

ISSN: $1305-578 \mathrm{X}$

Journal of Language and Linguistic Studies, 16(4), 1833-1853; 2020

\title{
The effect of co-teaching on advanced EFL learners' writing ability
}

\author{
Parisa Yeganehpour a 1 iD, Elham Zarfsaz b iD \\ a Ibrahim Çeçen University, Ağrl, Turkey \\ ${ }^{b}$ IAU of Urmia, Urmia Branch, Iran
}

\section{APA Citation:}

Yeganehpour, P., \& Zarfsaz. E. (2020). The effect of co-teaching on advanced EFL learners' writing ability. Journal of Language and Linguistic Studies, 16(4), 1833-1853.

Submission Date:13/07/2020

Acceptance Date:21/10/2020

\begin{abstract}
Students need to be skilled writers to get involved in a literate society. Providing learners with effective and appropriate teaching approach can lead to an easier and better mastery of skills. One of these approaches may be co-teaching. This study investigates the effect of co-teaching for Iranian advanced EFL learners' ability to write. The co-teaching approach was taken as a treatment through which two teachers were cooperating simultaneously during the teaching writing process in the same class with the experimental group. The participants of the control group were taught traditionally by a single teacher during all class sessions. According to the data analyses after comparing the two groups, co-teachers have been more successful in improving the overall writing ability of the treatment group. The underlying rationale is one in which teaching a class with two teachers may first add to the variety of teaching styles, feedback giving, consultation and reviewing the teaching process that can lead to better teaching practice and also doubling the class time by increasing teacher-student interaction time.
\end{abstract}

(C) 2020 JLLS and the Authors - Published by JLLS.

Keywords: co-teaching; single teaching; experimental group; control group; treatment.

\section{Introduction}

Teaching in academic settings is known to be a multifaceted process. Effective tools and tactics together should be used in teaching language skills; therefore, the teaching process can even be considered more complex. Writing skill is considered as one of the main skills since it is a crucial component of literacy. As Coulmas (2003) puts it, it was Aristotle (1938) who probably gave the most widely quoted definition of writing:

"Words spoken are symbols of affections or impressions of the soul; written words are symbols of words spoken, just as letters are not the same for all men, sounds are not the same either, although the affections directly expressed by these indications are the same for everyone, as are the things of which these impressions are images" (p.115).

\footnotetext{
${ }^{1}$ Corresponding author.

E-mail address: pyeganehpour@agri.edu.tr
} 
Throughout modern world, the ability to write in English easily and fluently is becoming increasingly substantial as contact by language is becoming increasingly prominent. In order to participate in literate society, students need to be skilled writers. Additionally, for students to be academically successful, effective writing skills are needed. Emig (2019) claims that writing improves learning and boosts critical thinking skills; moreover, higher cognitive functions, such as interpretation and synthesis, only evolve with the help of verbal language, particularly written language.

Cooperative teaching method may be considered as a useful technique in EFL writing classes to teach writing. Morocoo and Aguilar (2002) refer to cooperative teaching as co-teaching, while others refer to it as collaborative teaching. Another term for co-teaching is team teaching. In other words, it is when two teachers are working together to improve teaching. Nonetheless, all terms tend to have one meaning: a transformation of teaching styles in which two or more educators with a shared set of skills operate in a coordinated manner to collectively educate heterogeneous groups of students both academically and behaviorally. Aliakbari and Nejad came across the idea of co-teaching in the search for effective teaching methods and strategies. They define co-teaching as "two teachers' collaborative practice of planning, teaching, and evaluating the educational program" (2013, p.1). Teachers aim to develop different strategies and techniques of co-teaching to achieve the content of the syllabus and to improve the academic performance of students. Nevertheless, EFL teachers will perform various tasks such as planning and organizing plus delivery and assessment to do an effective co-teaching (Aliakbari \& Bazyar, 2012). Likewise, successful co-teachers are described as inclusive, accountable for all pupils, and capable of maintaining a positive relationship with each other (Aliakbari \& Nejad, 2013). Students will benefit the greater level of experience, and complimentary models, therefore that increased collaborative instruction in the classroom would support students.

Co-teachers will be exposed to many advantages within the harmonious professionalism exchanged by both of them to teach writing. Co-teaching in this study considered as two teachers are responsible to teach essay writing in an EFL class, and they plan to teach together, plan instruction together, share teaching duties, and design all teaching processes. Regardless of which co-teaching approach is applied in the class, it is anticipated that both teachers should teach essay writing collaboratively to reduce the workload pressures on teachers, particularly in terms of curriculum material. It is assumed that the coteachers will support each other, show confidence, and clearly explain the co-teaching techniques they will use. This chapter is going to investigate the effect of co-teaching on advanced EFL learners' writing skill.

This study is presented in six sections. First section contains an introduction to the study, statement of the problem, and significance of the study. Section two presents a review of writing and co-teaching related literature and factors that influence the efficacy of co-teaching. Section three presents the methodology used to conduct the study, including a methodology overview, research design, research questions participant and setting process. Section four details data analysis and findings of the study. Section five represents a discussion of the themes that have emerged through the complete data analysis process. Section six describes the conclusions, implication, limitations, and suggestions for further research. List of references appear at the end of the thesis.

\subsection{Statement of the Problem and the Purpose of the Study}

The importance of writing in international communication and the complexity of this skill necessitate the application of appropriate teaching and learning strategies or approaches. Therefore, as Brown (2001) claims teaching this skill to the learners in a proper way is of utmost importance. The problem learners and teachers usually face it is that even in higher levels of education learners suffer poor writing skill. Thus, learners and teachers need to work harder and more on this complex skill. However, Gere 
(1992) and McCrimmon (1984), as cited in Asrobi \& Prasetyaningrum, (2017) assert that we should not think of more practice as the only solution of problems in writing. Problem of poor writing can be attributed to many factors including teachers' classroom practice (Hammadi \& Sidek, 2015).

In order to get a good writing, it needs to be visualized, arrange the thought, compose, study, and edit, therefore can focus on using language more specifically. Writing is "a complex process composed of many different kinds of activities that eventually result in that product" (Nightingale, 2000, p.135). In the same vein, Nunan (2001) asserts that "producing a coherent, fluent, extended piece of writing is probably the most difficult thing to do in a language learning process. It is something most native speakers never master, thus second language learners' challenges are enormous" (p.271). However, it is one of the vital skills in communication and knowledge organization. In contexts where English is taught as a foreign language, writing is usually overlooked at elementary stages of learning. In Iranian context, most EFL advanced learners' English writing is generally poor in terms of content, organization, vocabulary, and language use; however, they are supposed to have mastered various aspects of writing to meet their academic and sometimes interactional needs during the courses they have taken at schools or institutes.

Hence, providing the learners with a more effective and appropriate teaching approach can lead to easier and better mastery of this skill. One of these approaches can be co-teaching. By working together in the same class, with same students, teachers can observe and critique each other's teaching and assessing pedagogy, supporting each other to enhance students' learning outcomes. Therefore, this study will aim at investigating and comparing the effects of co-teaching vs. conventional one on improving learners' writing skill.

\subsection{Significance and Justification of the Study}

The support of a co-teaching partner inspires both teachers to test new strategies and techniques (Salend, Garrick Duhaney \& Montgomery, 2002). According to Vaughn, Schumm, and Arguelles (1997), managing the classroom, well-communication, and planning time are requirements of coteaching. Scruggs, Mastropieri and McDuffie (2007) claim that in co-teaching, two teachers jointly plan and teach in the same classroom to meet diverse students' needs in the general education classroom as well as to support each other in the education profession and teaching special skills such as writing. In the process which language learners construct knowledge by interacting with other students, co-teachers can learn from each other and develop new and creative ideas as they work together to solve problems, change curriculum, and create lessons. Co-teachers with each other's expertise can become aware of students' abilities and learning targets and can better be able to instruct the students as they coordinate learning objectives together.

Writing is considered to be the most difficult skill since it is a productive skill and the writer creates new language for communication and learning. It is known as an efficient contact style. Students are deemed to be able to express their thoughts in an organized way by teaching writing within a suitable strategy. It may allow students to communicate ideas, solve problems and appreciate their changing world (Hammadi \& Sidek, 2015).

Due to the importance of writing as mentioned above, the current study tried to improve teaching writing in English language classrooms by offering co-teaching strategy in EFL classrooms. This study is significant because it seeks to advance knowledge, more specifically writing skill in the field of language education. Additionally, through considering the study's results, practical considerations for enhancing co-teaching are offered. It is hoped that by evaluating the effectiveness of co-teaching on advance EFL learners writing performance, more competent language learners be trained using this strategy by schools and institutes. It also hoped that language teachers and educators apply the results 
of this study in their teaching writing and other skills; moreover, it is hoped that education authorities take the results into consideration in changing the class management system by using co-teaching strategy.

\section{Literature review}

\subsection{Teaching Writing}

Going back in time and investigating the history of teaching writing, it can be understood that this capacity was not given much scrutiny as is obvious from the lack of research studies related to this ability until the beginning of the last decade of the 20th century (Krashen, 1984). Long and Richard (2003) declared that during the 1990s, as English became the medium of international communication, teaching writing skill was given priority. Afterward, writing English as a foreign language started to play a progressively principal role in the lives of professionals in nearly every area and field.

Writing as an effective form of language is a major skill for language learners to advance their language knowledge and the teaching of this skill has turn out to be essential in foreign language classrooms. Writing as an internationally useful mode of communication has been part of the syllabus of English education among the four language skills (listening, speaking, reading, and writing) (Hyland, 2007). Foster (2013) claims that writing, as a way of communicating ideas, thinking, and learning content must be considered as a key means for language learning as well as communication. Besides, writing is not only a way of expressing ideas and feelings and exchanging information or a way of using words to express oneself but also it is a social activity in which people interact with their partners (Taki \& Fardafshari, 2012).

Writing is considered as a challenge which many foreign/second language learners face. It is an important component not only in education, but also in life especially for those people who do not know how to express their feelings verbally, thus they use words and letters to translate their feelings, ideas, and thoughts. When anyone learns how to write very well, this helps him/her to produce an excellent plot and a logical argument. In addition, writing gives the reader a positive impression about the writer as a professional person and a good thinker because this writer enables the reader to live with him/her that experience he/she has written about just through words (Ibrahim, 2013).

\subsection{Co-Teaching for EFLs in the Writing Classroom}

In the classroom, there are diverse methods to advance toward writing. In any case, best exercise will lean on many factors like the variety of student, the text being studied, the school system, etc. A recent systematic literature review about teaching writing skill concluded that among the different approaches that have been studied the success of teaching writing, three approaches have been the most common: "product approach, process approach, and genre approach". All of the approaches have their own weaknesses and strengths, but they are also supportive to each other. (Badger \& White, 2000; Paltridge, 2004; Hayland, 2007; Grami, 2010).

The traditional model of teaching writing frequently fails to put teachers together to effectively use selected approaches (Darragh, Picanco, Tully, \& Henning, 2011). "The model leads to many wellprepared teachers who, shut the classroom door to the outside world and do not view their profession as a collaborative one since their apprenticeship and first exposure to the profession was a solo one" (Darragh et al., 2011, p. 86). It may be difficult for a teacher alone to apply a mix of teaching approaches simultaneously therefore, co-teaching can be used as a useful teaching technique to pave the way in teaching writing to language learners and improve poor classroom conditions. Guyton \& McIntyre 
ascertained that "preparation of cooperating teachers for their roles is effective in developing a more positive context" with cooperating teachers more likely (a) to be active listeners, (b) use different teaching methods and (c) interact with their student more efficiently. Teachers and collaborating teachers with whom they are paired have no supported teaching relationship prior to the teaching experience of the student. "Research indicates that planned, purposeful talking with each other about roles and objectives might alleviate contradictions and the frustrations that flow from them" (Guyton \& McIntyre, 1990, pp. 520-524).

Bauler, Kang, Afanador-Vega and Stevenson (2019) investigated the impact of co-teaching on writing classes and supported its fostering effect. Their findings revealed that the co-teachers attained an amplified capability to scaffold their teaching to carry their students' writing success. Co-teachers' split practices let in a responsive visibility of students' academic language and writing progress, simulating for negotiations about writing, fixing particular scaffolds for academic language, and occasions for talking and sharing ideas about writing. These practices allowed the ESOL and content teacher to start and spilt uniform and harmonized roles through planning, instruction, and rating.

Dove and Honigsfeld (2017) demonstrated that the containment of English Language Learners through co-teaching has been a legitimate key to handle the problem of alleviating the number of ELLs in US schools. Teacher association and co-teaching have been supported as a potent approach that can nourish teachers' leading and boost student learning. This differs from the "pull out" model of ELLs from the mainstream classroom for specially designated periods of English Language Development which have represented restricted outcomes to help ELLs success (Alvarez, Ananda, Walquí, Sato, \& Rabinowitz, 2014; Potter, 2011; Valdés, 2001).

\subsection{Factors that Influence the Efficacy of Co-teaching on Teaching Writing to Language Learners}

Various factors have been identified as necessary for successful, productive co-teaching. These include co-planning (Honingfeld \& Dove, 2010; Murawski, 2012); the educators' role (Cook \& Friend, 1995; Hang \& Rabren, 2009; Brusca-Vega, Brown, \& Yasutake, 2011); a shared philosophy between co-teachers (Keefe \& Moore, 2004; Mastropieri et al., 2005; Pugach \& Winn, 2011; Simmons \& Magiera, 2007); and knowledge of content (Mastropieri et al., 2005), co-teaching strategies, and evidence-based practices (McKenzie, 2009; McLeskey \& Brownell, 2015; Scruggs et al., 2007). Furthermore, there are short explanations for these factors in the next part.

\subsubsection{Co-planning}

According to Honingfeld and Dove (2010), co-planning is undeniably the most significant component of the collaborative instructional cycle. Co-teaching does not happen without it, thus when teams of teachers enter a classroom without ample preparation, it may at best be described as shared real estate. The success of any true co-teaching practice depends on the success of co-planning (p. 25).

Research that has been done by Pratt, Imbody, Wolf, \& Patterson (2016) indicates that among the multiple factors that influence co-teaching efficacy, co-planning is one of the integral parts for successful application of co-teaching on a special skill and co-teachers must agree on all aspects of the classroom environment, including instructional methodology, classroom discipline, and their respective roles during instruction. They also emphasize the use of synchronous and asynchronous technologies to make co-planning between teachers and teacher-students. To this end, co-planning is imperative for coteaching to be effective (Murawski, 2012). Olcott, Nieroda, \& Crandall (2014) in a formative experiment of a writing project examined the professional development on writing through co- teaching and coplanning during a period of 35 years in the US. According to the findings of their study, the institute 
attained its pedagogical goals i.e. students by contributing to a working digital story screened at the public celebration created better writing assignments.

\subsubsection{Assigned role}

Successful co-teaching relies on two equal partners partnering to advise and assess a shared student group (Friend \& Cook, 2004). The partners need to engage in conversation about professional roles, specialized skill sets, and classroom practices to build and maintain a good co-teaching partnership (Cook \& Friend, 1995). Nevertheless, delegated tasks have long been taken as a concern in co-teaching classrooms. In the one teacher/ one assistant co-teaching model, special educators work in a more passive role. If one teacher tries to control the teaching, the relationship will fail, and as a result, the experience of co-teaching is going to be less successful (Brusca-Vega, Brown, \& Yasutake, 2011). Hang and Rabren (2009) state that the classroom's behavior training is seen by both general and special educators as being more accountable. A clearly defined role and function in the classroom would be expressed by special educators who contribute to the teaching preparation and review of the curriculum, tests, and classroom management issues affecting co-teaching students with disabilities (Hang \& Rabren, 2009). A lack of job specificity limits the ability of special educators to provide training of high quality.

According to the statements of the Maryland state department of education (2012), co-teachers may facilitate the process of teaching writing to language learners by assigning a special role such as writing on the board, checking students' answers, and sharing responsibilities to deliver instruction to all of the language learners.

\subsubsection{Knowledge}

Content knowledge of the teachers is an essential factor in co-teaching approach. Having higher content knowledge can assist teachers to have a dynamic role in the co-taught environment. The teachers' knowledge of the curriculum, content, students, and the pedagogy of teaching helps them make better and efficient decisions. On the other hand, the quality and quantity of specially designed instruction the students receive decreases in the case of a lack of content training (Nichols, Dowdy, \& Nichols, 2010). Also, successful co-teaching depends on a clear understanding of teaching strategies and models of co-teaching. Teachers receiving special training for teaching special skills by co-teaching are more confident in implementing these practices (Martinussen, Tannock \& Chaban, 2011). Therefore co-teachers should have special knowledge about teaching writing to pave the learners' way with a more useful method.

\subsubsection{Shared philosophy}

Two teachers must find a common vision on which to base the decisions they make in a co-taught writing classroom. A considerable criterion to be successful in the co-teaching models is the professional relationship formed between teachers before and during the co-teaching experience. "The first step in successful implementation includes establishing a co-teaching relationship by developing goals, expectations, and roles as well as understanding setting demands" (Solis, Solis, Perez, Manjarrezb, \& Floresa, 2012, p. 499).

When co-teachers build a common vision, their co-teaching theory, goals, and intellectual values must be addressed. A common philosophy of sharing goals and mutual respect for each other's activities will influence the co-teachers' ability to learn and develop from each other and the students ' progress in their teaching process. Co-teachers will take advantage of their experiences to improve better if they suit each other well (Pugach \& Winn, 2011).

Volunteerism is often cited in the literature as a means to identify co-teachers who may be wellmatched and have similar philosophies (Keefe \& Moore, 2004). Co-teachers who are assigned, rather 
than volunteer, to work together during writing classes may report incompatibility leading to a "dysfunctional partnership .... resulting in de-professionalism among special education teachers and frustration among the regular education teachers" (Isherwood \& Barger, 2008, p. 125). In the same vein, Friend (2015) stated that "It's less like a marriage and more like a business partnership. Each teacher brings important knowledge and skills to the classroom, and they learn from each other without trying to be interchangeable" (p. 21).

\subsubsection{Self-efficacy}

Self-efficacy is the teachers ' perception that their position in the classroom is significant and that it can be done effectively. In the classroom, educational consistency, choice of curriculum, and inspiration have been related to how co-teachers view their positions in teaching writing (Solis et al., 2012). Silverman (2007) indicated that good co-teachers need a constructive inclusive mindset, assuming that all students are capable of learning, and hold high-level knowledge and learning values. He argued that these contribute to a clear sense of self-efficacy, reinforcing the views of the teachers that they are capable of fulfilling their position in the classroom and hence perceive that they are productive professionals in the secondary classroom. According to Cook and Friend (2004) before starting to coteach and regularly revisiting these topics, co-teaching participants must participate thoroughly with these topics to facilitate open communication.

\section{Method}

Beginning from the premise that using the co-teaching approach as a technique through which two teachers working simultaneously in the same class during the teaching process have an effect on enhancing the writing success of EFL learners, this research was an attempt to analyze the effects of coteaching on the writing performance of Iranian advanced EFL learners.

This study aimed to answer the following research question:

Does co-teaching have any significant effect on Iranian advanced level students' writing skill improvement?

Based on the research question, the following null hypothesis was formulated:

H01: Co-teaching has no significant effect on Iranian advanced level students' writing skill improvement.

For the analysis, a quasi-experimental research design was used. When it is not feasible for the researcher to randomly select the subject and distribute it to treatment groups without disturbing the academic programs of the schools involved in the study, quasi-experimental design can be used (Gall, Gall, \& Borg, 2007). Furthermore, it should be noted that in this study the effect of two types of teaching practice, co-teaching and traditional single teaching strategies, on EFL writing performance was investigated. Through this quasi-experimental design, the relation between one dependent variable; EFL writing skill, and one independent variable: teaching strategies (co-teaching and single teacher traditional teaching) was investigated. The information about the variables is summarized and illustrated in Table 1. 
Table 1. Variables of the study

\begin{tabular}{cc}
\hline Dependent Variable & Writing Performance \\
\hline Independent Variable & Teaching Strategy \\
\hline Control Variables & Language Proficiency Level \\
\hline
\end{tabular}

\subsection{Participants and setting}

The study population included all 41 Iranian students learning English at a language institute in Urmia, Iran. In order to select homogeneous subjects in terms of language proficiency, the participants were selected from four groups of English classes at the same level who were at the age group between 15 to 21 . All the participants were students of 15th level English classes who were considered as advance students in this institute. The language proficiency level of the learners who were supposed to participate in the study was determined by the teachers at the institute by taking the previous term test scores on their oral and written placement tests. Originally 49 students participated in this study, but after homogeneity process, 8 students whose scores in Oxford Quick Placement Test were too high or too low, were excluded from the study, since it seemed they showed heterogeneous performance in comparison to the whole participants. The final sample size was 41 subjects. Both the experimental and the control group consisted of only one class. Two teaching approaches, co-teaching and traditional single teacher strategy, were used as the instruction strategies. The former was investigated in the experimental group and the latter in the control group. With a complete awareness of the process and the goal of the study, the students in all groups accepted to take part in the pre-test and the post-test taken by the researcher one week before the treatment and one week after the treatment respectively. Majority of the students in related institute were female, thus gender was not considered as a variable and only female students took part in this study.

\section{Results}

Oxford Quick Placement Test was used to attain optimum homogeneity among the subjects with respect to their level of language skills. The test consisted of 60 questions to be replied in 45 minutes by the participants. The scoring criteria for this test are presented in Table 2.

Table 2. Scoring criteria for Oxford quick placement test

\begin{tabular}{cc}
\hline Proficiency Level & cut off points \\
\hline Breakthrough & $1-18$ \\
Elementary & $19-25$ \\
Lower-intermediate & $26-30$ \\
Intermediate & $31-35$ \\
Upper-intermediate & $36-45$ \\
Advanced & $46-60$ \\
\hline
\end{tabular}

The descriptive statistics of the results of Oxford Quick Placement Test are given in Table 3. A total of 49 Iranian EFL learners learning English at this institute were given the homogeneity test. 
Table 3. Descriptive statistics for the oxford quick placement test

\begin{tabular}{cccccc}
\hline & N & Minimum & Maximum & Mean & Std. Deviation \\
\hline Proficiency Test & 49 & 30 & 52 & 41.25 & 3.41 \\
& & & & & \\
\hline
\end{tabular}

Furthermore, according to the participants' grades in the above exam, 41 female students from the entire test takers' population were chosen as the research group. As mentioned earlier, participants belonged to the advance level of proficiency who are measured by the Oxford Quick Placement Test. The participants were then split randomly and assigned to two groups in order to act as the study's control and experimental groups.

\subsection{Pre-test and Post-test}

After the participants had been homogenized with respect to their grades on the Oxford Quick Placement test, they were asked to write an essay of about 100 words on a genuine validated TOEFL writing test with some small allocated time changes to make them manageable for the students. The purpose was determining homogeneity of learners with respect to their writing skills before the treatment was administered. After getting the scores of the participants in both groups, the normality of the data distribution was assessed by Shapiro Wilk tests.

The style of test chosen for this study was in the format of essay writing (thesis statement, body and conclusion) based on what the students had learned within the institute during their English education; thus, they were familiar with the structure of the exam. Participants were given 40 minutes to work on each pre-and post-test writing.

To ensure that the scoring procedure was sufficiently reliable to be used for statistical investigation, participants ' writings were scored by the researcher and another qualified teacher in the institute with similar qualities of the researcher using Brown's suggested weighting scale (2001) to establish the reliability between raters.

The aim of post-test was to compare the performances of the control and experimental classes after the treatment. As with the pre-test, the topic for this essay was another genuine validated TOEFL writing test. It is worth mentioning that the post-test was given to the participants of both groups one week after the treatment. The results of normality or abnormality are shown in Table 4.

Table 4. Test of normality (Shapiro-Wilk)

\begin{tabular}{ccccc}
\hline & Group & Statistic & df & Sig. \\
\cline { 2 - 5 } Pre-test & Experimental & .871 & 20 & .496 \\
& Control & .964 & 19 & .132 \\
Post-test & Experimental & .903 & 20 & .320 \\
& Control & .771 & 19 & .162 \\
\hline
\end{tabular}

According to Table 4, the statistic of Shapiro-Wilk obtained for experimental pre-test scores was .87 and the corresponding degree of significance was .49. Since the p-value obtained was greater than.05, it can be concluded that the first normality hypothesis can be rejected and then the experimental pre-test scores' normality is maintained. Similarly, the distribution of pre-test scores for experimental group was normal. In the same line, with respect to the second normality hypothesis, the Shapiro-Wilk figures obtained for control pre-test scores were .96 and the corresponding significance point was .13. Because the p-value obtained was greater than .05 , it can be inferred that the distribution of control pre-test scores was also normal. 
As it is shown in table 4, the Shapiro-Wilk statistic obtained for the post-test scores of experimental was .9 and the correspondent significance level was .32. Since the observed p-value was larger than .05, it can be argued that the third hypothesis of normality was rejected and hence the alternative hypothesis was accepted; that is, the distribution of the post-test scores for experimental was normal. The same was true for the post-test scores of control group since the observed p levels was larger than .05. As it is shown in Table 4, the distribution of the all sets of data were normal. As the results show, Pearson coefficient correlation test and $t$ tests can be used for data analysis.

The researcher had all the essays scored by three raters, the researcher and one trained professional instructor using the weighting scale to measure the writing suggested by Brown (1991). Also, the interrater reliability of the pre-test scores was checked. The Pearson Product-Moment Correlation was calculated between the scores rated by the mentioned raters. The results are shown in Table 5 .

Table 5. Correlation coefficient for the writing pre-test

\begin{tabular}{|c|c|c|c|}
\hline & & Rater One & Rater Two \\
\hline Rater One & $\begin{array}{l}\text { Pearson Correlation } \\
\text { Sig. (2-tailed) }\end{array}$ & 1 & $\begin{array}{l}.73 \\
.000\end{array}$ \\
\hline & $\mathrm{N}$ & 41 & 41 \\
\hline Rater Two & $\begin{array}{l}\text { Pearson Correlation } \\
\text { Sig. (2-tailed) }\end{array}$ & $\begin{array}{l}.73 \\
.000\end{array}$ & 1 \\
\hline
\end{tabular}

Based on the results shown in Table 5, a correlation coefficient of .73 was obtained indicating that there existed a high degree of go-togetherness between the given scores.

\subsection{Data Collection and Analysis}

The design of the present study is quasi-experimental group design including an experimental group and a control one. The former was taught using co-teaching approach teaching writing; while the latter was tight all the materials in class using traditional single teacher. In this study, the teaching strategy was considered as the independent variable and the writing performance was regarded as the dependent variables. In order to ensure the least difference among the proficiency level of the students, Oxford Quick Placement Test (2004) was administered. Then the researcher selected available classes as the control group and experimental one (21 students in experimental group and 20 in control one). Before the treatment phase the participants of both groups took part in the pre-tests of genuine TOEFL writing exams. This research was planned for twelve sessions; each session lasted for one and a half hour. The learners of the experimental group were under treatment. In this study, the co-teaching approach was taken as a strategy through which two teachers were cooperating simultaneously during the teaching process in the same class. That is, the participants on experimental group were taught by two teachers; their regular class teacher in addition to another English teacher well-known to the students in their institute. The topics of the writing practices for every session of treatment were chosen from their English course book Cambridge Prism level 4 which they covered throughout the term. Although the participants in control group were also asked to write paragraphs on topics of interest during the twelvesession usual course, they did not undergo the procedures of treatment in the experimental group. They just were taught by one single teacher during all class sessions. This discrepancy has done to compare the success of control and experimental groups in writing essay by considering the effect of co-teaching.

At the end of the twelve-session program, the participants of both groups took another genuine TOEFL writing exam as post-test. The participants' writing samples were scored thrice by three distinct scorers: the researcher and another scorer; then, correlation analysis was performed to determine the inter-rater reliability of the process. The teacher ensured the learners that the study was not mainly 
concerned with evaluation but rather improving their writing skill. Also, they were reassured about the confidentiality of the collected data.

During the scoring process, it should be mentioned that the participants' writing essays were scored based on the weighting scale to assess the overall ability of their writing performance. Comparing the advantages and drawbacks of analytic and holistic scoring, Brown (2001) believes that the former is more beneficial for the EFL program than the latter. Brown's (1991) weighting scale (cited in Brown, 2001) was applied in the current study to measure the students' writing performance. This scale of writing evaluation is an analytic scale which consists of six categories. Having been developed in 1991, it is one of the most reliable scales for rating learners' writing in an EFL context. In this scale, all aspects of EFL writing are taken into account; therefore, it is suitable for evaluating any sort of writing performance.

\subsection{Comparing the pre-test scores}

The results of the descriptive statistics of pre-test comparison are given in Table 6 . Table 6 sets forth that the number of participants was 41 . A mean score of 61.03 with a standard deviation of 2.44 is obtained for the control group, while the mean score of 56.34 with a standard deviation of 4.63 is gained for the experimental group. Statistically, an independent sample t-test was used to check the observed difference. The results are shown in Table 7.

Table 6. The descriptive statistics indices of writing pretest for control and experimental

\begin{tabular}{ccccc}
\hline & Grouping & N & Mean & Std. Deviation \\
\hline Writing Pre-test & Experimental & 21 & 56.34 & 2.446 \\
& Control & 20 & 61.03 & 4.630 \\
\hline
\end{tabular}

Table 7. Independent samples t-test comparing groups' performance on the writing pre-test

\begin{tabular}{|c|c|c|c|c|c|c|c|c|c|c|}
\hline & & \multicolumn{4}{|c|}{$\begin{array}{c}\text { Levene's } \\
\text { Test for } \\
\text { Equality of } \\
\text { Variances }\end{array}$} & \multicolumn{3}{|c|}{ t-test for Equality of Means } & & \\
\hline & & & & & & \multicolumn{5}{|c|}{$\begin{array}{c}95 \% \text { Confidence } \\
\text { Interval of the } \\
\text { Difference }\end{array}$} \\
\hline & & $\mathrm{F}$ & Sig. & $\mathrm{T}$ & Df & tailed) & Difference & Difference & Lower & Upper \\
\hline \multirow[t]{2}{*}{$\begin{array}{l}\text { Writing Pre- } \\
\text { test }\end{array}$} & $\begin{array}{c}\text { Equal variances } \\
\text { assumed }\end{array}$ & .041 & .657 & -.566 & 39 & .363 & -4.692 & .366 & -.938 & .523 \\
\hline & $\begin{array}{c}\text { Equal variances } \\
\text { not assumed }\end{array}$ & & & -.572 & 38.828 & .379 & -4.692 & .363 & -.931 & .516 \\
\hline
\end{tabular}

As shown in the tables, the study included all the 41 scores collected from the administration of the pre-test scores. The purpose of the study was to serve the evidence that whether there is a significant difference between the scores of the control and the experimental group. According to table 6, the observed t was .56 and the observed significance level was .37 which was far above the critical value .05 . Therefore, it can be argued that the observed $t$ was not significant and it can be inferred that there was no statistically significant difference between the mean scores obtained from these two classes in pre-test. 
After being informed of the Experimental and Control Groups ' homogeneity with regard to their writing skill in the target language (English), the researcher began applying intervention, i.e. using team teaching technique to instruct the experimental group for 12 sessions. The post-test was then carried out for both groups. Comparison was made to address the study's research question and examine the effectiveness of learner writing strategies promoting their pre- and post-test scores. Once again, an interrater relationship was determined using the Pearson Product-Moment Correlation before evaluating the scores.

Table 8. Correlation coefficient for the writing post-test

\begin{tabular}{cccc}
\hline & & Rater One & Rater Two \\
Rater One & Pearson Correlation & 1 & .81 \\
& Sig. (2-tailed) & & .000 \\
Rater Two & N & 41 & 41 \\
& Pearson Correlation & .81 & 1 \\
\hline
\end{tabular}

The researcher used the same technique as used for the pre-test inter-rater reliability to check for the inter-rater reliability in the post-test. As it is shown in table 8, the correlation between the scores scored by the raters was performed to the Pearson Product-Moment. A statistically significant coefficient correlation of .81 was obtained indicating a high degree of go-to-togetherness between the given scores by the two raters.

\subsection{Comparing the pre and post-test scores}

The researcher compared participants pre and post test score to find the answer to the proposed research question, whether the used strategy was effective in improving learners' writing performance. The results are shown in the following tables.

Table 9. Descriptive Statistics of the Results of the Pre and Posttest of Experimental Group

\begin{tabular}{cccc}
\hline & N & Mean & Std. Deviation \\
\hline Pair & 21 & 56.34 & 2.446 \\
& 21 & 73.12 & 3.267 \\
\hline
\end{tabular}

Table 10. Paired Samples t-test for the Experimental Groups' Performance on the Pre and Post-tests

\begin{tabular}{|c|c|c|c|c|c|c|c|c|c|}
\hline & & \multicolumn{5}{|c|}{ Paired Differences } & \multirow[b]{3}{*}{$\mathrm{t}$} & \multirow[b]{3}{*}{$\mathrm{df}$} & \multirow{3}{*}{$\begin{array}{l}\text { Sig. (2- } \\
\text { tailed) }\end{array}$} \\
\hline & & \multirow[b]{2}{*}{ Mean } & \multirow{2}{*}{$\begin{array}{c}\text { Std. } \\
\text { Deviation }\end{array}$} & \multirow{2}{*}{$\begin{array}{l}\text { Std. Error } \\
\text { Mean }\end{array}$} & \multicolumn{2}{|c|}{$\begin{array}{c}95 \% \text { Confidence } \\
\text { Interval of the } \\
\text { Difference }\end{array}$} & & & \\
\hline & & & & & Lower & Upper & & & \\
\hline Pair 1 & $\begin{array}{l}\text { Experimental Pre- } \\
\text { test Experimental } \\
\text { Post-test }\end{array}$ & -16.78 & 2.131 & .336 & -5.897 & -4.527 & -15.493 & 20 & .017 \\
\hline
\end{tabular}

Based on the data shown in Table 9, in pre- and post-test the mean scores were 56.34 and 73.12 for the experimental group. Clearly, there was a considerable difference between the mean results of the post-test and the related pre-test scores. To check that the reported discrepancy is statistically significant, a paired sample t-test was conducted to compare the mean scores in the pre- and post-writing test to show the efficacy of co-teaching. Table 10 summarizes the findings. 
Based on the results, it was determined that the difference between the group's mean scores was statistically significant as the degree of significance $(p=.01)$ was less than .05 . Hence, the null hypothesis was rejected. Therefore, it was concluded that the participants were able to improve their writing performance when taught using co-teaching strategy.

Table 11. Descriptive statistics of the results of the pre and post-test of control group

\begin{tabular}{cccc}
\hline & N & Mean & Std. Deviation \\
\hline Pair & 20 & 61.03 & 4.630 \\
& 20 & 70.42 & 3.193 \\
\hline
\end{tabular}

Table 12. Paired samples t-test for the control groups' performance on the pre and post-tests

\begin{tabular}{|c|c|c|c|c|c|c|c|c|c|}
\hline & & \multicolumn{5}{|c|}{ Paired Differences } & \multirow[b]{5}{*}{$\mathrm{t}$} & \multirow[b]{5}{*}{$\mathrm{df}$} & \multirow{5}{*}{$\begin{array}{l}\text { Sig. }(2- \\
\text { tailed) }\end{array}$} \\
\hline & & \multirow[b]{4}{*}{ Mean } & \multirow{4}{*}{$\begin{array}{c}\text { Std. } \\
\text { Deviation }\end{array}$} & \multirow{4}{*}{$\begin{array}{l}\text { Std. Error } \\
\text { Mean }\end{array}$} & \multirow{3}{*}{\multicolumn{2}{|c|}{$\begin{array}{l}95 \% \text { Confidence } \\
\text { Interval of the } \\
\text { Difference }\end{array}$}} & & & \\
\hline & & & & & & & & & \\
\hline & & & & & & & & & \\
\hline & & & & & Lower & Upper & & & \\
\hline Pair 1 & $\begin{array}{l}\text { Control Pre-test } \\
\text { Control Post-test }\end{array}$ & -9.39 & 3.413 & .246 & -5.897 & -4.527 & -12.493 & 19 & .041 \\
\hline
\end{tabular}

In order to testify the significance of the observed difference and hence to check the writing performance of the control group, the researcher adopted a paired samples t-test analysis to compare the mean scores. Based on the results, the difference between the mean scores was statistically significant since the significance level equaled .04 which was less than .05 (table 12). Hence, it was concluded that the participants in control group also were able to improve their writing performance when being taught by a single teacher. However, due to the significance of the performance difference within both groups, the researcher compared the post-tests of both groups taking writing homogeneity of all participants.

\subsection{Comparing the Post-Test Scores}

As within group comparison confirmed; co-teaching approach helped the participants improve their writing. Due to the fact that the teaching approach in both groups were successful in improving participants' performances, the researcher decided to compare their post-test performances since before treatment they were homogenous in terms of writing ability. The post-tests' descriptive and analytic statistics are presented in the Tables 13 and 14, respectively.

Table 13. Descriptive statistics of the results of the post-test of experimental and control groups

\begin{tabular}{lllll}
\hline & & N & Mean & Std. Deviation \\
\hline Pair & Experimental Post-test & 21 & 73.12 & 3.267 \\
& Control Post-test & 20 & 70.42 & 3.193 \\
\hline
\end{tabular}


Table 14. Independent sample t-test comparing groups' performance on the writing post-test

\begin{tabular}{|c|c|c|c|c|c|c|c|c|c|c|}
\hline & & $\begin{array}{r}\text { Lev } \\
\text { Tes } \\
\text { Equa } \\
\text { Vari }\end{array}$ & $\begin{array}{l}\text { ne's } \\
\text { for } \\
\text { lity of } \\
\text { ances }\end{array}$ & \multicolumn{7}{|c|}{ t-test for Equality of Means } \\
\hline & & \multirow[b]{2}{*}{$\mathrm{F}$} & \multirow[b]{2}{*}{ Sig. } & \multirow[b]{2}{*}{$\mathrm{T}$} & \multirow[b]{2}{*}{ df } & \multirow{2}{*}{$\begin{array}{l}\text { Sig. (2- } \\
\text { tailed) }\end{array}$} & \multirow{2}{*}{$\begin{array}{c}\text { Mean } \\
\text { Difference }\end{array}$} & \multirow{2}{*}{$\begin{array}{l}\text { Std. Error } \\
\text { Difference }\end{array}$} & \multicolumn{2}{|c|}{$\begin{array}{c}95 \% \text { Confidence } \\
\text { Interval of the } \\
\text { Difference }\end{array}$} \\
\hline & & & & & & & & & Lower & Upper \\
\hline $\begin{array}{l}\text { Writing } \\
\text { Post-test }\end{array}$ & $\begin{array}{c}\text { Equal variances } \\
\text { assumed }\end{array}$ & .023 & .545 & -.346 & 39 & .031 & 2.701 & .526 & -.838 & .615 \\
\hline & $\begin{array}{c}\text { Equal variances } \\
\text { not assumed }\end{array}$ & & & -.341 & 38.828 & .031 & 2.701 & .523 & -.831 & .616 \\
\hline
\end{tabular}

The study measured the post-test mean scores at the end of the course when both classes had completed the treatment period to demonstrate that the applicable techniques influenced the writing of the subjects equally. The descriptive indices of these scores are shown in Table 13. As shown in this table, there was a slight difference in two groups' mean scores of post-tests. In order to testify the significance of the observed difference the researcher adopted an independent t-test analysis to compare the mean scores. The results are shown in table 14.

The findings showed a considerable differential on outperformance between the experimental and control groups [ $\mathrm{t}(39)=-.34, \mathrm{p}=.031$ ], which means that co-teaching has been much more successful in improving the overall writing ability of the treatment group.

\section{Discussion}

One of the most prominent issues that captured scholars ' attention today is to arrange an efficient teaching and learning situation for all students to facilitate their learning. This therefore rests to a large extent on the use of correct methods in teaching. Although a great number of the previous studies had confirmed different impact of different types of teaching in various educational contexts, current research confirms the positive effect of using co-teaching on teaching writing to English as foreign language learners when two teachers are teaching simultaneously in cooperation.

This study broadly deals with the impacts of co-teaching strategy on the general writing skills of Iranian advanced EFL learners compared to the traditional single teacher instruction. Based on the results obtained, it is now quite feasible to think carefully about the research question in the field of empirical evidence and to compare the current findings of the study with other findings of the related studies in order to make the results more tangible. The researcher, though, used a control group that was not treated as equal to the experimental group. Comparing the two strategies, it was found that coteaching has been much more successful in improving the overall writing ability of the treatment group. According to the findings of the analyses done on the given data, it was concluded that the participants were able to improve their English writing performance when taught using co-teaching strategy. The underlying rational is one in which teaching a class with two teachers can first add to the variety of teaching styles, feedback giving, consultation and reviewing the teaching process that can lead to better teaching practice and also doubling the class time by increasing teacher-student interaction time.

Findings of this study are in line with Honigsfeld \& Dove, 2008; Honigsfeld \& Dove, 2017; Guyton \& McIntyre, 1990; and Bauler, Kang, Afanador- Vega \& Stevenson, 2019; who assert, co-teaching has 
a positive impact on learning of the participants since, it increases the number of students getting individual attention. It means that students in co-teaching classes were likely to get more individual attention and had the opportunity to participate more often. Another rationale for the efficacy of coteaching and its outperformance in comparison to traditional single teacher may be due to presence of two teachers which according to Gillespie and Israetel (2008) makes material more accessible and helps learners' understanding of the curriculum.

The findings of current study are in contrast with the study performed by Aliakbari and Bazyar (2012). They studied the impact of co-teaching on the general language skills of EFL learners. Unlike this study which found that co-teaching was effective in improving learners writing skill and also it outperformed single teacher class, in a quasi-experimental study, they found that parallel teaching as one of the models of co-teaching didn't seem to come in line with the result of other studies. Although the participants performed differently on the post-test, the difference was not significant. Therefore, they concluded that in this particular situation, parallel teaching model did not result in better results than traditional teaching method.

The result of study was performed by Aliakbari and Nejad (2013) was in contrast with current research too. Aliakbari and Nejad (2013) studied the efficacy of training by the team in improving the grammar skill of the learner. The result revealed that students who were instructed using co-teaching did not perform higher than students who provided conventional ELT instruction. Also the results of studies had done by Alvarez, Ananda, Walquí, Sato and Rabinowitz (2014) and Valdés (2001) reported limited results of success in co-teaching that has not led to a better result in language teaching and learning issues.

Another study that reviewed different results from current research was the one performed by Potter (2011). The purpose of his study was to evaluate whether students with minor disabilities had a greater mastery of communication tests when taught in co-teaching. Unlike current result, their research result revealed that there was no significant difference in students' performance in co-teaching and separate environment as well as no better performance in co-teaching setting for students with minor disabilities.

\section{Conclusions}

The main purpose of the present study is to bring methods and theories into the classrooms and display practical approaches of writing for foreign language learners. As a matter of fact, the utmost aim of the chapter was to figure out the effectiveness of using co-teaching in an EFL context especially on learning and teaching writing skill to learners. The results demonstrated that using co-teaching strategy had positive impact on learners' writing improvement. The specific analysis of the obtained data revealed that there is difference between co-taught learners writing performance and traditional single teacher taught ones.

A paired sample t-test was performed to seek the influence of using co-teaching on writing skill to reject the posed null hypothesis. A separate independent sample t-test was subsequently used to help the researcher draw conclusions that participants of co-teaching strategy performed better in promoting their writing than traditional single teaching ones.

While much has been done to figure out the effectiveness and utility of co-teaching, it seems that little attention has been paid in particular in the sense of EFL and use of co-teaching in different situations. According to Nevin and Thousand (2010) there are a few research which have studied the effect of co-teaching on various pedagogical issues such as teaching techniques, styles, approaches, methods, skills, ands sub skills of language such as reading, writing, vocabulary and grammar. 
Regarding the findings of current study which indicated the efficacy of co-teaching over single teacher, it can be concluded that since conducting co-teaching, the goal of teachers is to develop different strategies and solutions to achieve the material of the syllabus and increase the academic performance of students. On behalf of students, Aliakbari \& Nejad (2010) assert that good co-teachers are compassionate, responsible to all students and willing to build a positive relationship with each other hence, they can affect the learners' motivation and ultimately language learning. In the same way, Andrews \& Wooten, (2005) believe that co-teaching has several advantages over traditional singleteacher teaching method. According to Andrews \& Wooten, (2005) this teaching method includes providing multiple learning experiences, reducing duplication in teaching and encouraging teamwork and teacher communication. Another main advantage of co-teaching according to Benoit, (2001) is that more detailed observation of students engaged in the learning process can occur.

Totally, the current research's groundbreaking results strengthened the environment for further study and helped teachers easily communicate the significance of writing to language learners through new teaching methods.

\subsection{Implications of the study}

The noteworthy implications of this study include useful pedagogical emphasis for all curriculum developers, instructors, learners, and all those interested with EFL teaching. Consequently, the findings of this study would shed more light on developing EFL learners' language skills and may contribute positively to the field of language teaching in Asian contexts.

- This study had focused on comparison effect of co-teaching and single teacher strategies on writing achievement of Iranian advanced EFL learners. For instance, the findings of the study can be used by material designers and researcher in designing appropriate materials and tasks to be used in cotaught classes at certain levels of language learning.

- Another implication of this study can be for the teacher trainers who can also instruct the student-teachers how to teach various language skills in harmony with another peer in order to take advantage of each other's experience and assistance.

- The findings can also be beneficiary for teachers who can get the best of co-teaching strategy since teaching along with another peer can cause versatility, interaction, and cooperation which can lead to better results.

- The results of current study can also be important and helpful to language learners, since knowing the efficacy of co-teaching over the traditional techniques, learners can attend the classes or institutes which offer a co-taught class that can help them learn much better by providing the broader level of experience, complementary styles, and enhanced classroom teaching dynamic.

\subsection{Limitations of the study}

Like any other research certain inevitable weaknesses affect the current research. Therefore, when evaluating the findings, a great caution should be observed. As a matter of fact, the results can be generalized after due consideration of the described disadvantages. Many key factors have constrained this research.

- First, the number of the participants setting available for the purpose of the study by the institute administrators was less than originally intended by the researcher.

- Furthermore, the research sample was selected from Urmia, West Azerbaijan because it was not possible for the researcher to go to another city and use a large group of advance students. 
- Another limitation was due to experiment duration, the experiment lasted for 12 sessions according to the institute's rule, but the researcher needed more time to get the best result.

- The other limitation was due to the teachers, since the teachers chosen by the researcher for coteaching were not sufficiently familiar with the type of co-teaching because most institutes preferred traditional teaching to co-teaching affected by financial issues which could have a bad effect on the research result.

- Another limitation of this research was that it concentrated only on writing promotion so that the findings could not be applied to other language skills and elements such as syntax, listening or reading.

- Moreover, since the researcher were not able to obtain the necessary permissions from the authorities of the institute to include all proficiency levels, the study was limited only to the advance female learners.

\subsection{Suggestion for further research}

It is clear that no study is complete and is bound to certain limitation and delimitations, hence, different studies under different conditions can be conducted to firstly confirm or question the findings of current study and also to broaden the results realm of current study.

- Considering the number of subjects, the easiest way to conduct further experiments in different language centers is to include a large number of EFL learners in each category to reach better and more precise results.

- The participants of the present study were selected among advance level excluding the elementary and intermediate levels. Hence, the current study can be done by other researcher with learners of elementary and intermediate levels. With both male and female gender.

- The study lasted only for twelve sessions. Lengthening the duration of the study may lead to other results.

- Gender may be added to the subsequent studies as a comparing factor.

- Opinions of students toward this method and perspectives of the management toward it can be studied.

- The extent that universities/ institutes are able to fallow co-teaching also, can be studied.

\section{Ethics Committee Approval}

The author(s) confirm(s) that the study does not need ethics committee approval according to the research integrity rules in their country (Date of Confirmation: July 13, 2020).

\section{References}

Aliakbari, M., \& Bazyar, A. (2012). Exploring the impact of parallel teaching on general language proficiency of EFL learners. Pan-Pacific Association of Applied Linguistics, 16(1), 55-71.

Aliakbari, M., \& Nejad, A. (2013). On the effectiveness of team teaching in promoting learners' grammatical proficiency. Canadian Journal of Education, 36(3), 5-22. 
Al-Hammadi, F., \& Sidek, K., (2015). Academic writing in the Yemeni EFL context: History, challenges and future research. The Effects of Brief Mindfulness Intervention on Acute Pain experience: An Examination of Individual Difference, 1, 167-174.

Alvarez, L., Ananda, S., Walqui, A., Sato, E., \& Rabinowitz, S., (2014). Focusing formative assessment on the needs of English language learners. West ED.

Andrews, K., \& Wooten, B. (2005). Closing the gap: helping students identify the skills employers want. NACE Journal, 64(4), 49-52.

Asrobi, Maman, \& Prasetyaningrum, A. (2017). Trait Based Assessment on Teaching Writing Skill for EFL Learners. English Language Teaching, 10(1), 199-212.

Badger, R., \& White, G. (2000). Process genre approach to teaching writing. ELT Journal, 54(2), 153160.

Bauler, C.V., Kang, E., Afanador-Vega, A., \& Stevenson, A. (2019). My partner always helps me: Exploring two co-teachers' practices to support writing in a first-grade linguistically diverse elementary class. TESL-EJ, 24(2),1-18.

Benoit, R. (2001). Team teaching tips for foreign language teachers. The Internet TESL Journal, 7(10), $15-32$.

Brown, H. D. (2001). Teaching by principles: An interactive approach to language pedagogy, 2nd ed. California: San Francisco State University.

Brown, J. D. (1991). Do ESL and English faculties rate writing samples differently? TESOL Quarterly, 25(4), 587-603.

Brusca-Vega, R., Brown, K., \& Yasutake, D. (2011). Science achievement of students in co-taught, inquiry based classrooms. Learning Disabilities: A Multidisciplinary Journal, 17(1), 23-31.

Coulmas, F. (2003). Writing systems: An introduction to their linguistic analysis. Cambridge University Press: Cambridge.

Cook, L., \& Friend, M. (1995). Co-teaching: Guidelines for creating effective practices. Focus On Exceptional Children, 28(3), 1-16.

Darragh, J. J., Picanco, K. E., Tully, D., \& Henning, A. S. (2011). When teachers collaborate, good things happen: Teacher candidate perspectives of the coteach model for the student teaching internship. AILACTE Journal, 8, 83-104.

Dove, M. G., \& Honigsfeld, A. M. (2017). Co-teaching for English learners: A guide to collaborative planning, instruction, assessment, and reflection. Thousand Oaks, CA: Corwin.

Emig, J. (2019). Writing as a mode of learning. College Composition and Communication, 28(2), 122128.

Foster, E., \& Rotoloni, B. (2013). Reciprocal teaching. The University of Georgia.

Friend, M., \& Cook, L. (2004). Co-teaching: Principles, practices and pragmatics, Quarterly Special Education Meeting Albuquerque, NM.

Friend, M. (2015). Welcome to co-teaching 2.0. Educational Leadership, 73(4), 16-22.

Gall, M., D., Gall, J. P., \& Borg, W. R. (2007) Educational research: An introduction. Boston: Pearson Education. 
Gillespie, D., \& Israetel, A. (2008). Benefits of co-teaching in relation to student learning. Paper represented at Annual Meeting of the American Psychological Association, Massachusetts.

Grami, G. M. A. (2010). The Effects of Integrating Peer Feedback into University-Level ESL Writing Curriculum: A Comparative Study in a Saudi Context (Unpublished doctoral dissertation) Newcastle University, Newcastle.

Guyton, E., \& McIntyre, D. J. (1990). Student teaching and school experiences. In W. R. Houston, M. Haberman, \& J. Sikula (Eds.), Handbook of research on teacher education: A project of the Association of Teacher Educators (pp.514- 534). New York, NY: Macmillan.

Hammidi, F. A., \& Sidek, H. M. (2015). An analytical framework for analyzing secondary EFL writing curriculum: Approaches for writing and preparation for higher education. International Education Studies, 8(1), 203-221.

Hang, Q., \& Rabren, K. (2009). An examination of co-teaching: Perspectives and efficacy indicators. Remedial and Special Education, 30(5), 259-268.

Honigsfeld, A., \& Dove, M. (2008). Co-teaching in the ESL classroom. Delta Kappa Gamma Bulletin, 74(2), 8-14.

Honigsfeld, A., \& Dove, M. (2010). Collaboration and co-teaching: Strategies for English learners. Thousand Oaks, CA: Corwin.

Hyland, K. (2003). Teaching and Researching Writing. Harlow: Longman.

Ibrahim, M. G. (2013). The Effect of Using Facebook on Improving Students' Writing Skills in English (Unpublished master's thesis). Al-Najah National University, Palestine.

Isherwood, R. S., \& Barger, A. R. (2008). Factors affecting the adoption of co-teaching models in inclusive classrooms: One school's journey from mainstreaming to inclusion. Journal of Ethnographic \& Qualitative Research, 2, 121-128.

Keefe, B., \& Moore, V. (2004). The challenge of co-teaching in inclusive classrooms at the high school level and what the teachers told us. American Secondary Education, 32, 77-88.

Krashen, S. D. (1984). Writing: Research, theory, and applications. Oxford: Pergamon Institute of English.

Long, M. H., \& Richards, J. C. (2003). Series editors' preface. In B. Kroll (Ed.), Exploring the dynamics of second language writing (pp. 15-16). Cambridge: Cambridge University Press. McMillan Encyclopedia. (1986). London: McMillan Limited.

Martinussen, R., Tannock, R., \& Chaban, P. (2011). Teachers' reported use of instructional behavioral management practices for students with behavior problems: Relationship to role and level of training in ADHD. Child Youth Care Forum, 40, 193-210.

Mastropieri, M. A., Scruggs, T. E., Graetz, J., Norland, J., Gardizi, W., \& McDuffie, K. (2005). Case studies in co-teaching in the content areas: Successes, failures, and challenges. Intervention in School and Clinic, 40, 260-270.

McKenzie, R. G. (2009). A national survey of pre-service preparation for collaboration. Teacher Education and Special Education: The Journal of the Teacher Education Division of the Council for Exceptional Children, 32, 379-393.

McLeskey, J., \& Brownell, M. (2015). High-leverage practices and teacher preparation in special education (Document No.PR-1). Retrieved from University of Florida, Collaboration for Effective 
Educator, Development, Accountability, and Reform Center website: http://ceedar.education, ufl.edu/tools/best-practice-review/

Morocco, C. C., \& Aguilar, C. M. (2002). Co-teaching for content understanding: A schoolwide model. Journal of Educational and Psychological Consultations, 13(4), 315-347.

Murawski, W. W. (2012). Observing co-teaching: What to ask for, look for, and listen for. Intervention in School and Clinic, 46(3), 174-183.

Nevin, A. I., Thousand, J. I., \& Villa, R. A. (2009). Collaborative teaching for teacher educators: What does the research say? Teaching and Teacher Education, 25, 569-574.

Nichols, J., Dowdy, A., \& Nichols, C. (2010). Co-teaching: An educational promise for children with disabilities or a quick fix to meet the mandates of No Child Left Behind? Education, 130, 647-651.

Nightingale, P. (2000). Improving student writing. In S. Makoni (Ed.), Improving teaching and learning in higher education: A handbook for Southern Africa (pp. 131-166). Johannesburg: Witwatersrand University Press.

Nunan, D. (2001). Research Methods in Language Learning. Cambridge: Cambridge University Press.

Olcott, K. C., Nieroda, J., \& Crandall, B. R. (2014). Co-planning and co-teaching in a summer writing institute: A formative experiment. Teaching/Writing: The Journal of Writing Teacher Education, 3(2), 13-34.

Paltridge, B. (2004). Approaches to genre in ELT. In J. Cummins, \& C. Davison (Eds.), International handbook of English language teaching (pp. 931-943). Springer US.

Pincas, A. (1982). Teaching English writing. Macmillan Press.

Potter, J. (2011). New literacies, new practices and learner research: Across the semi-permeable membrane between home and school. Kansanvalistusseura: Helsinki, Finland

Pratt, S. M., Imbody, S. M., Wolf, L. D., \& Patterson, A. L. (2016). Intervention in School and Clinic 1-7: Hammill Institute on Disabilities.

Pugach, M. C., \& Winn, J. A. (2011). Research on co-teaching and teaming: An untapped resource for induction. Journal of Special Education Leadership, 24(1), 36-46.

Salend, S. J., Garrick Duhaney, L. M., \& Montgomery, W. (2002). A comprehensive approach to identifying and addressing issues of disproportionate representation. Remedial and Special Education, 23(5), 289-299.

Scruggs, T. E., Mastropieri, M. A., \& McDuffie, K. A. (2007). Co-teaching in inclusive classrooms: A metasynthesis of qualitative research. Exceptional Children, 73(4), 392-416.

Silverman, J. C. (2007). Epistemological beliefs and attitudes toward inclusion in preservice teachers. Teacher Education and Special Education, 30, 42-51.

Simmons, R. J., \& Magiera, K. (2007). Evaluation of co-teaching in three high schools within one school district: How do you know when you are truly co-teaching? Teaching Exceptional Children Plus, $3(3), 23-37$.

Solis, M., Solis, A., Perez, H., Manjarrezb, N., \& Floresa, M. (2012). Microbial decolouration of azo dyes: a review. Process Biochem, 47, 1723-1748.

Taki, S., \& Fardafshari, E. (2012). Weblog-based Collaborative Learning: Iranian EFL Learners' Writing Skill and Motivation. International Journal of Linguistics, 4(2), 412-429. 
Valdés, G. (2001). Learning and not learning English: Latino students in American schools. New York: Teachers College Press.

Vaughn, S., Schumm, J. S., \& Arguelles, M. E. (1997). The ABCDEs of co teaching. Teaching Exceptional Children, 30(2), 1-10.

\section{Eş-öğretimin ileri EFL öğrencilerinin yazma becerisine etkisi}

\section{$\ddot{O} \mathbf{z}$}

Öğrencilerin okuryazar bir topluma katılabilmeleri için yetenekli yazarlar olmaları gerekir. Öğrencilere etkili ve uygun bir öğretim yaklaşımı sağlamak, daha kolay ve daha iyi bir beceri ustalığına sağlayabilir. Bu yaklaşımlardan biri eş- öğretim olabilir. Bu çalışma, İranlı ileri EFL öğrencilerinin yazma becerisine yönelik eş- öğretimin etkisini araştırmaktadır. Ortak öğretim yaklaşımı, deney grubuyla aynı sınıfta öğretim yazma sürecinde iki öğretmenin aynı anda işbirliği yaptı̆̆ı bir yöntem olarak ele alınmıştır. Kontrol grubunun katılımcıları tüm sınıf oturumlarında geleneksel olarak tek bir öğretmen tarafından öğretildi. İki grubu karşılaştırdıktan sonra yapılan veri analizlerine göre, yardımcı öğretmenler deney grubunun genel yazma yeteneğini geliştirmede daha başarılı olmuşlardır. Temel gerekçeye göre, iki öğretmeni olan bir sınıfin öğretilmesinin ilk önce çeşitli öğretim stilleri, geri bildirim verme, danışma ve daha iyi öğretim pratĭgine yol açabilecek ve aynı zamanda öğretmen- öğrenci etkileşim süresini artırarak sınıf süresini iki katına çıkarabilecek bir konudur.

Anahtar sözcükler: eş- öğretim; tek öğretim; deney gurubu; kontrol gurubu; işlem

\section{AUTHOR BIODATA}

Dr. Parisa Yeganepour is a Professor assistant at Ağrı İbrahim Çeçen University, Department of Translation and Interpretation Studies, School of Foreign Languages. Her research interests include Language Teaching Methodology and Individual Differences.

Elham Zarfsaz holds a Ph.D. in English Language Teaching from Turkey and a BA and MA from University of Tabriz, Iran. Her main research interests are tech-assisted language teaching, integration of technology to language learning and psychology of teaching and learning. 